\title{
TRACE ELEMENT ACCUMULATION IN TREE RINGS OF PINUS HALEPENSIS DURING THE LAST 140 YEARS
}

\author{
A. PANTERA ${ }^{1, *}$ \\ A. M. PAPADOPOULOS ${ }^{1}$ \\ M. ORFANOUDAKIS ${ }^{2}$
}

\author{
${ }^{1}$ TEI Lamias, Forestry and Natural Resources \\ Management Department, 36100 Karpenissi \\ ${ }^{2}$ Aristotele University of Thessaloniki \\ School of Forestry and Natural Environment \\ Forest Soil Laboratory, P.O. BOX 271, 54124.Greece \\ *to whom all correspondence should be addressed: \\ e-mail: pantera@teilam.gr
}

\section{ABSTRACT}

The trace element analysis of Aleppo pine (Pinus halepensis Mill) as a function of tree age, was achieved by the tree-ring sampling method, in a polluted region of Attica, Greece. The elements quantitatively determined for the last 140 years by atomic spectrophotometry analysis were: $\mathrm{Cu}, \mathrm{Fe}, \mathrm{Zn}, \mathrm{Mn}$ and $\mathrm{Pb}$. With the exception of $\mathrm{Pb}$, all other elements tend to increase for the time period of this study. A very interesting fluctuation was noted between the years 1920 to 1960-1970, a time coinciding with the major industrial activity of the area. The decreasing concentration of all elements for the last few decades may be attributed to the increasing environmental awareness as well as respective regulations posed by the government and the E.U. The radial distribution of concentrations in annual tree rings provides adequate information that, in most of the cases, can be related to the history of the tree and the biological processes interacting on its growth. Soil, litter, air deposits and water are important nutrient sources contributing to changes in elemental concentration in the annual rings.

\section{INTRODUCTION.}

The emission of air pollutants to the environment is a serious problem, as these elements tend to accumulate and increase in various parts of an ecosystem (Nakos, 1980). Forest trees can accumulate certain concentrations of trace elements and are usually able to compensate this stress temporarily by means of regulation and adaptation mechanisms. However, long-term stress leads to the weakening of particular small or even large tree groups. That is the result from nutrient imbalances, expressed as nutrient stresses (Gebauer and Schulze, 1988) followed by decreased growth (Hirano and Morimoto, 1999), and/or defoliation (Oszlányi, 1997).

Heavy metals and other pollutants are absorbed to a varying degree by numerous plants at different parts of a plant species. Chemical composition of various vegetative parts is an important parameter to determine the nutrient status of a plant (Ferreti et al., 1993). Tree rings were used to construct climatic records and study the relationship between growth and climatic conditions (Fritts, 1976; Schweingruber, 1988). Only recently, tree ring mineral element concentrations have been used as biomonitors of chemical parameters of the environment such as soil solution chemistry and atmospheric pollution (Penninckx et al., 1999; Guyette and Cutter, 1994). Since tree rings correspond to years of tree life, tree-core sample mineral element content can be correlated to past environmental conditions, pollution or contamination. The aim of the study was to determine the occurrence and distribution of certain trace elements in tree rings of Aleppo pine trees (Pinus halepensis ssp halepensis), in the Diomedes Botanical Garden, located close to a heavily polluted area of Athens, Greece. 
Additionally, effort was made to relate the distribution of these elements with tree growth and climate parameters.

\section{MATERIALS AND METHODS}

\subsection{Study area}

The Diomedes Botanical Garden covers an area of 165 ha in the northern slope of the mountain Aegaleo. It is located $7 \mathrm{Km}$ from the centre of Athens and can be characterized as a suburban forest of the western suburbs of the capital. It is close to the Thriasian Plain, a region with industrial plants such as cement works, oil refinery plants, distilleries, steel mills, and a variety of other industries. It is also surrounded by major high-way arteries, such as the National road Athens-Corinthus, the lera Odos and the Shisto Avenue that assemble daily major circulatory pressure most hours of the day. Phytotoxic concentration of ozone has been documented for this area (Saitanis, 2003). The soil is mostly calcareous with average to null slopes; average depth is $15-30 \mathrm{~cm}$ reaching even $70 \mathrm{~cm}$ in the Eastern side, with high clay content, and small penetrability. The forest mainly consists of Aleppo pine (Pinus halepensis ssp halepensis) and, at spots, by calabrian pine (Pinus halepensis ssp brutia), cypress (Cupressus sempervirens) and other species derived from previous reforestation attempts. Old native Aleppo pine stands grow on the foothill of the forest from which samples were collected for this research.

\subsection{Core and wood sampling}

Tree samples were collected from a pure Aleppo pine stand of the Diomedes Botanical Garden during the years 2003 to 2004. A total of 28 living and dead trees (Fig 1) were sampled. During the year 2003, 37 tree cores selected from living trees chosen based on the old age, health and the absence of injuries. Specifically, one or two core samples were selected from the northern part of each tree trunk. For trees growing on inclining sites two core samples were selected, one from the upper and one from the lower part of the inclination. Sample blocks of the stem $(50 \mathrm{~cm}$ thick) from $5 \mathrm{old}$, wind-fallen during the last winter, trees were removed at breast-height.

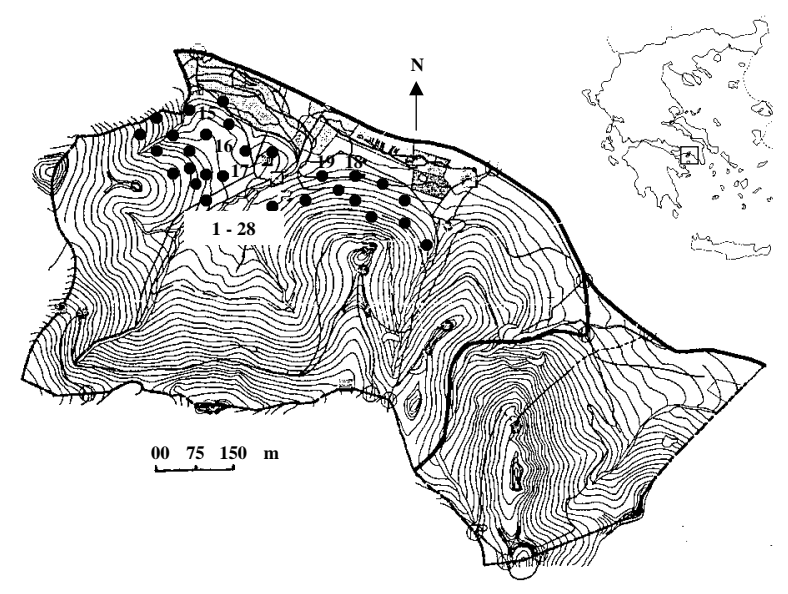

Figure 1. Chart of the Diomedes Botanical Garden indicating the position of the 28 sampled trees

All 37 core and the 5 block samples were dried under laboratory conditions until constant weight. Consequently, the samples were smoothed up to the point that the tree rings were easily recognized for analysis. The next step comprised of the cross dating and the counting of tree ring to the nearest $0.01 \mathrm{~mm}$ using the Windendro system. Sections of 10 years each were identified and separated from the 5 dated block samples and for the time period from 1870 to 2003 generating samples of 14 decades. 


\subsection{Tree-ring chemical analysis}

In order to have enough dry material to run the chemical analysis the wood chips extracted were correlated with ten years of growth. For that purpose, wood chips were extracted from 10 year wood sections. The wood chips were cracked with a mill to $1 \mathrm{~mm}$ wood fragments. Approximately $2 \mathrm{~g}$ of dry wood fragments were used for the analysis. The wood fragments were diluted with the acid digestion method, with acid solution consisting of $500 \mathrm{ml} \mathrm{HNO}_{3}$, $100 \mathrm{ml} \mathrm{H}_{2} \mathrm{SO}_{4}$ and $50 \mathrm{ml} \mathrm{HClO}_{4} 60 \%$ solution (Alifragis and Papamichos, 1995). The $60 \%$ $\mathrm{HClO}_{4}$ used in order to avoid any violent reactions from the resins occurred in the wood. The wood samples were placed in $30 \mathrm{ml} \mathrm{Kjeldhal} \mathrm{tubes} \mathrm{on} \mathrm{a} \mathrm{hot} \mathrm{plate} \mathrm{with} 120-130^{\circ} \mathrm{C}$ and $6 \mathrm{ml}$ of acid solution added. To avoid any loss of material the tubes were taped with small funnels. The temperatures rose gradually in order to avoid any spills and the samples remained there until thin white fumes appeared. The final solution filtered with Whatman No44 filter paper to $50 \mathrm{ml}$ volumetric flask. $\mathrm{Cu}, \mathrm{Fe}, \mathrm{Zn}, \mathrm{Mn}$, and $\mathrm{Pb}$ concentration was estimated with the use of Atomic absorption, (Perkin Elmer 3100), directly to the 50ml filtered solution.

\subsection{Statistical analysis}

Climate is the major factor affecting tree growth (Fritts, 1976). Of the climatic factors low precipitation and, specifically, summer drought may pose major stress limiting tree growth for the Mediterranean area (Mooney, 1983). For that reason and mainly, because water affects nutrient solubility, only rainfall was used for correlations. However, temperature will be also used for comparisons in the future.

Elements concentrations were correlated with the decade tree-ring width as well as with the mean decade precipitation. As hydrological year was considered the time period from October of a year (n) up to September of the following year $(n+1)$, period generally accepted for dedroclimatological and dendroecological studies in the Mediterranean region (Serre-Bachet, 1985).

All the precipitation data derived from the Athens National Observatory (NOA).

\section{RESULTS AND DISCUSSION}

\subsection{Climate and growth results}

The growth of Aleppo pine, a typical Mediterranean species, positively correlates to precipitation. The comparison of the precipitation curves of the hydrological years with the tree annual tree width of the period 1870-2003, revealed that the tendency line of tree-ring width follows the precipitation tendency (Fig. 2). This tendency has been well documented for Aleppo pine in many previous researches (Serre-Bachet, 1991; Papadopoulos et al., 2001; Papadopoulos et al., 2005), documenting the importance of precipitation to tree growth. Specifically, Papadopoulos et al. (2001), reported that winter and spring precipitations positively correlate to tree-ring width of the species in Greece.

Precipitation (doted line) and tree-ring width of Aleppo pine (s olid line)

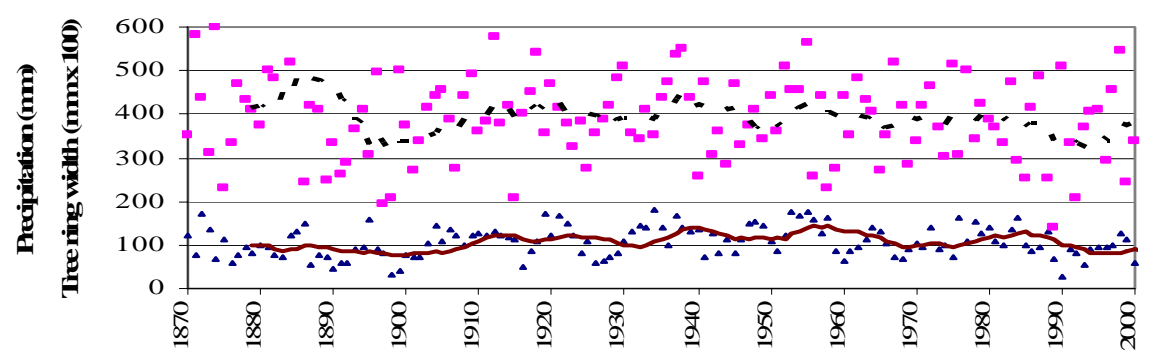

Figure 2. Tendency (moving average) of mean chronology of Aleppo pine tree rings width (continuous line), and annual precipitation (dotted line) of the hydrological years 1870 to 2004. Precipitation data were derived from the Athens National Observatory (NOA) 


\subsection{Elements concentration}

With the exception of $\mathrm{Pb}$, all other elements tend to increase for the time period of this study. A very interesting fluctuation was noted between the years 1920 to 1960-1970. This time coincides with the major industrial activity of the area and it is possibly attributed to this fact. The decreasing concentration of all elements for the last few decades may be attributed to the increasing environmental awareness as well as respective regulations posed by the government and the E.U.

There is a certain tendency noted for $\mathrm{Cu}$ concentrations to increase, as is presented in Figure 3. Nakos (1980) found that increased concentration of $\mathrm{Cu}$ in the soil relates to increased $\mathrm{Cu}$ concentration in the needles of Aleppo pine. However, the same author found no obvious effect of copper concentration to tree growth. No relationship exists between Cu concentration and Aleppo pine tree growth.

Cu concentration of tree rings per decade

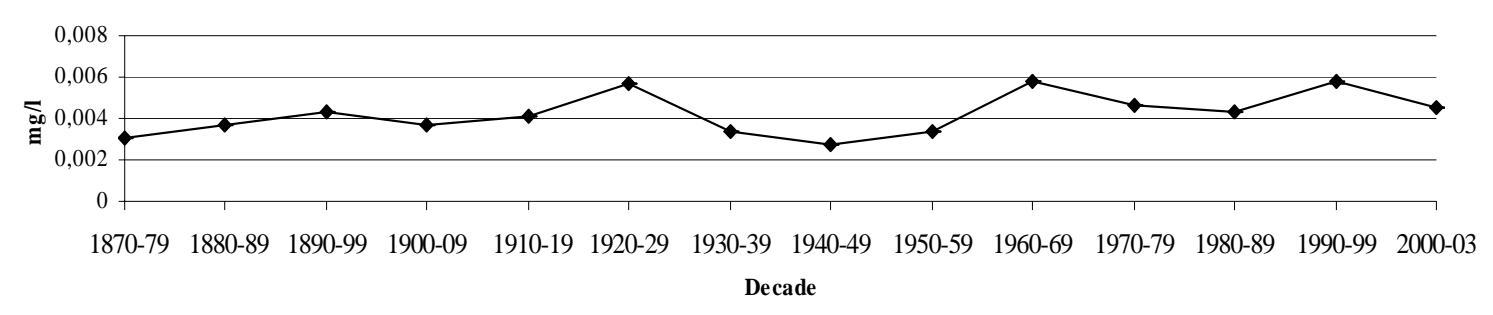

Figure 3. Copper concentration in $\mathrm{mg}^{-1}$ for the study period

Even though $\mathrm{Cu}$ deficiencies can be noted in some acid soils (Bohn et al., 1985), the precipitation level of the 1940-1950 decade can not be related to the concentration of the element. Similarly, Cu peaks noted during the decades 1920-29, 1960-69 and 1990-99 can only be hypothetically be attributed to atmospheric pollution. Interestingly enough, the correlation coefficient of $\mathrm{Cu}$ concentration and tree-ring width was found -0.46 , indicating a possible negative effect. This subject will be further investigated.

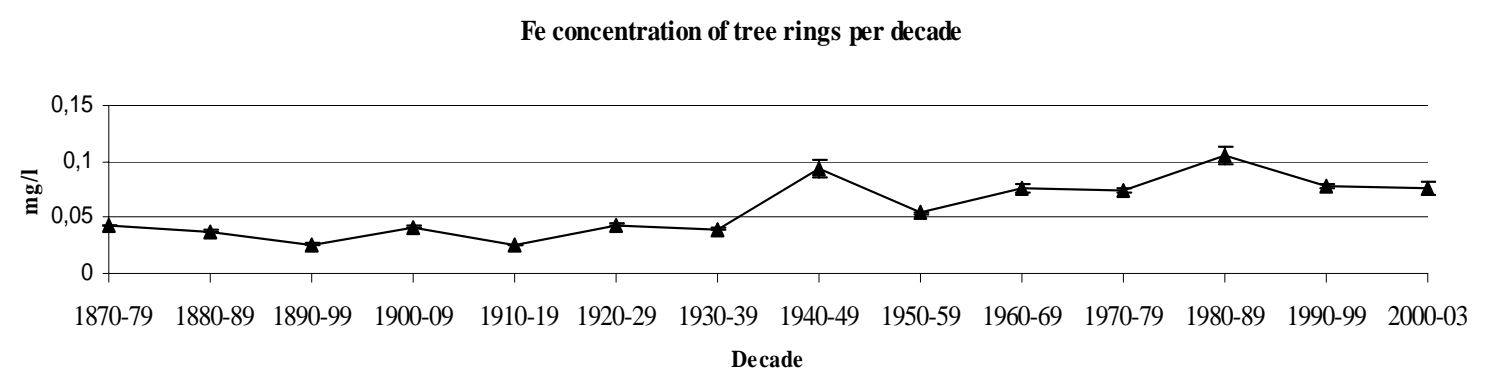

Figure 4. Iron concentration in $\mathrm{mg} \mathrm{I}^{-1}$ for the study period

Fe concentration (Fig. 4) has been significantly increasing during the last decades. No significant changes are noted from 1870 to 1930 , following an abrupt increase. This time coincides with the opening of major steel plant, the "Halivourgia", first opened on 1930 and later relocated to a closer to the site area on 1940. Fe readily responds to possible change in the soil conditions, and specifically, on alkaline soil conditions the $\mathrm{Fe}^{+2}$ form is found which is available to the plants. There was no correlation between Fe concentration and tree-ring width (c.c. -0.01). 
Zn concentration of tree rings per decade

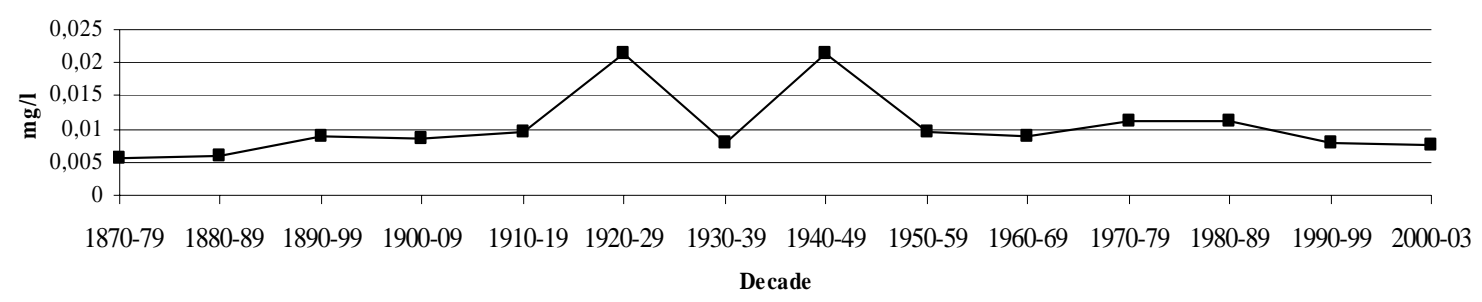

Figure 5. Zinc concentration in $\mathrm{mg} \mathrm{I}^{-1}$ for the study period

Zink uptake by plants in soils of high $\mathrm{pH}$ and concentrations of calcium carbonate can be problematic as $\mathrm{Zn}$ solubility in soils decreases at increasing soil pH values (Kiekens, 1995). Zn concentrations (Fig. 5) show two maximum picks during the 1920-29, similarly to $\mathrm{Cu}$, and the 1940-49 decades. Further investigation is necessary to determine the possible cause of such imbalances, possibly due to increased $\mathrm{N}$ or Ca depositions. Fiedler et al., 1990), positively correlated needle $\mathrm{Zn}$ content to $\mathrm{N}, \mathrm{K}, \mathrm{Ca}, \mathrm{Mn}$ and Fe. Minor fluctuations are noted for the rest of the time period, giving the general idea that $\mathrm{Zn}$ concentration have remained constant. $\mathrm{Zn}$ to tree-ring width coefficient of correlation was 0.21 of and it can be hypothesised that it indicates a possible positive correlation. This will be further investigated.

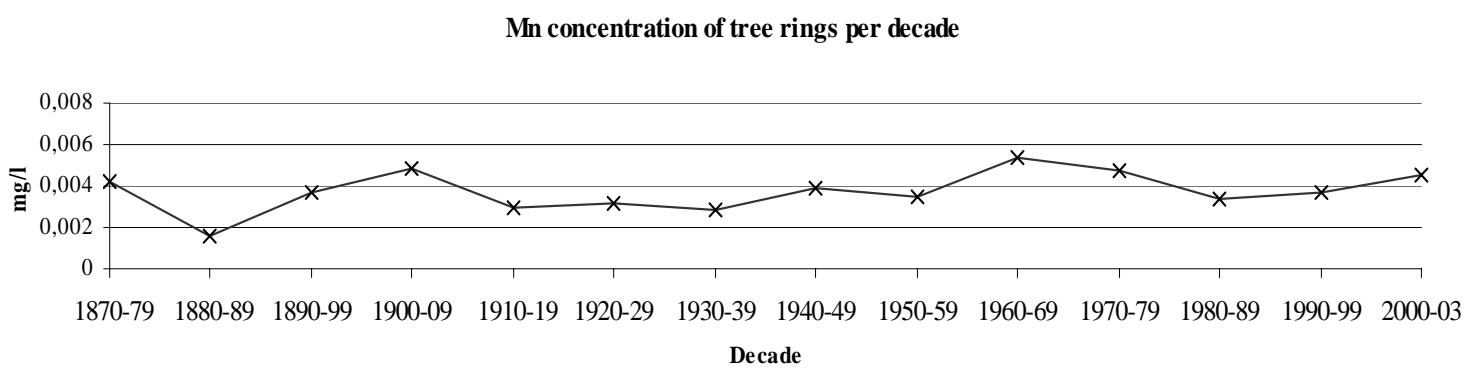

Figure 6. Manganese concentration in $\mathrm{mg}^{-1}$ for the study period

$\mathrm{Mn}$ concentration showed various fluctuations (Fig. 6), ending to a similar to the beginning level. Mn coefficient of correlation to tree-ring width was -0.2 , and it can be only hypothesised that it indicates a possible negative tendency. However, this subject will be further investigated.

Pb concentration of tree rings per decade

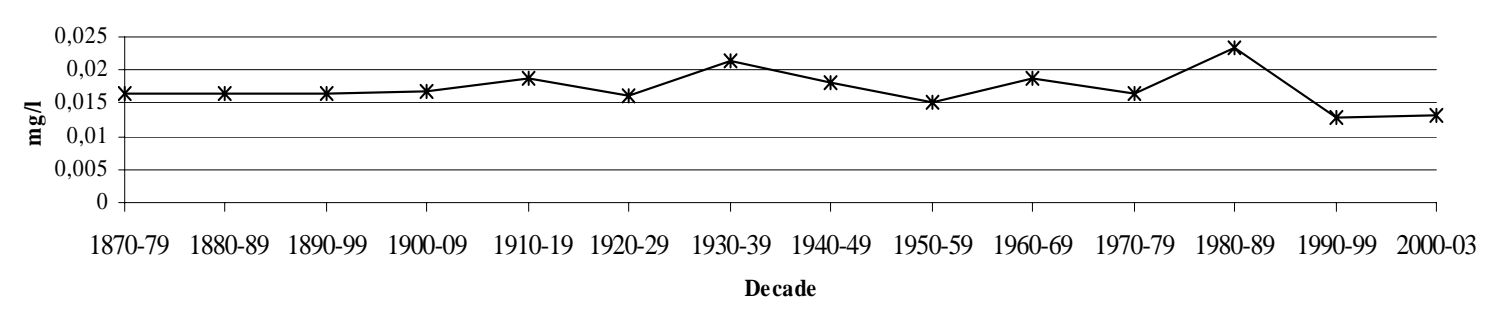

Figure 7. Lead concentration in $\mathrm{mg}^{-1}$ for the study period

Pd concentration (Fig. 7) decreases after the 1980-89 decade years, where the free of Pd gas was introduced in Greece. Pb coefficient of correlation to tree-ring width was -0.2, and as with $\mathrm{Mn}$ it can be only hypothesised that it indicates a possible negative tendency.

Generally, there was no significant correlation among the trace elements concentration in the wood with the total rainfall. Specifically, the correlation coefficients were for $\mathrm{Cu}-0.25$, for Fe0.13 , for $\mathrm{Pb}-0.009$, for $\mathrm{Zn}-0.35$ and for $\mathrm{Mn}-0.22$. Therefore, any changes in the trace 
elements concentration should be related with changes in the soil conditions, (element availability) but possibly are related with changes in the concentration in the soil solution, due to increase of the element concentration in to the precipitants.

Pollutants may affect directly and indirectly nutrient imbalances, were probably is the case at the precent study. Ozone, besides its phytotoxicity to Aleppo pine (Saitanis, 2003), changes, as well as $\mathrm{SO}_{2}$ concentrations, the mycorrhizal species of the tree (Diaz et al., 1995). Therefore, changes in mycorrhizal fungal root colonisation may result to nutrient imbalances. Fast nitrogen cycling could affect the living condition of Aleppo pine, an oligotrophic species occupying poor soil sites. Nitrogen eutrophication may adversely affect forests grown on calcareous soils by developing nutrition imbalances between $\mathrm{N}$ and micronutrients, the solubility of which depends on soil pH values (Michopoulos et al., 2004). Climatic changes mainly due to increased $\mathrm{CO}_{2}$ concentrations are predicted to affect all forest stands (Rathgeber et al., 2000). Another pollutant documented to negatively affect Aleppo pine seedlings is acid rain (Matziris and Nakos, 1977). What so ever, acid rain has not been documented for the area and the subject will be further investigated in the future.

\section{CONCLUSIONS}

This research represents a first attempt to use tree-ring elemental concentration as indicator of previous pollution episodes. Generally, it appears that, similarly to foliar elemental concentration, tree ring elements respond to environmental inputs by altering their concentration.

The radial distribution of concentrations in annual tree rings provides adequate information that, in most of the cases, can be related to the history of the tree and the biological processes interacting on its growth. Soil, litter, air deposits and water are important nutrient sources contributing to changes in elemental concentration in the annual rings.

Investigation will be further conducted by including other areas as well. The main purpose will be to strengthen the hypothesis that trace elements concentration affects tree growth and that can be identified by the means of tree rings width and their elemental concentration.

\section{Acknowledgements}

This research was conducted in the framework of the "Climatic - Environmental Changes and Aleppo pine tree ring sensibility in the Attica basin" research project, under the "Environment - Archimedes" program and it was partially funded from the E.U. (75\%) and the Greek Government (25\%). The authors also wish to express their appreciation to Prof. Dr. D. Alifragis for his valuable advices with the chemical analyses.

\section{REFERENCES}

1. Alifragis D. and Papamichos N., (1995), Description, sampling and laboratory analyses of forest soil and vegetative tissues, Pub. Dedousis, Thessaloniki.

2. Bohn H.L., Mc-Neal B. and O-Connor G., (1985), Soil Chemistry, J. Willey \& Sons. New York.

3. Diaz G., Barrantes O., Honrubia M. and Gracia C., (1995), Effect of ozone and sulphur dioxide on mycorrhizae of Pinus halepensis Miller, Annales de Sciences Forestieres, 53(4), 849-856.

4. Ferreti M., Udisti R. and Barbolani E., (1993), Mineral nutrients and trace metals in tree rings ofPinus sp., Fresenius' Journal of Analytical Chemistry, 347(10-11), 467-470.

5. Fiedler H.J., Ilgen G. and Getahun G.B.A., (1990), Pot experiments on the zinc nutrition of spruce seedlings in relation to the new kind of forest decline, Fertlizer Research, 26(1-3), 237242.

6. Fritts H.C., (1976), Tree rings and climate, Academic Press, London.

7. Gebauer G. and Schulze E.D., (1988), Forest decline of spruce as a result of nutrient imbalance and nutrient stress, Aspects of Applied Biology, 17(2), 123-130.

8. Guyette R.P. and Cutter B.E., (1994), Barium and manganese trends in tree-rings as monitors of sulphur deposition, Water, Air Soil Poll., 73:213-223

9. Hirano T. and K. Morimoto (1999), Growth reduction of the Japanese black pine corresponding to an air pollution episode, Environmental pollution, 106, 5-12. 
10. Kiekens I., (1995), Zink, In: Heavy metals in soils. Alloway BJ. (ed), Blackie Academic and Professional, London, Glasgow.

11. Matziris D. and Nakos G., (1977), Effect of simulated "acid rain" on juvenile characteristics of Aleppo pine (Pinus halepensis Mill.), Forest Ecology and Management, 1, 267-272.

12. Michopoulos P., Baloutsos G., Economou A. and Nikolis N., (2004), Effects of nitrogen deposition on nitrogen cycling in an aleppo pine stand in Athens, Greece, Science of the Total Environment, 323, 211-218.

13. Mooney H.A., (1983), Carbon-gaining capacity and allocation patterns of Mediterranean climate plants, In: Mediterranean Type Ecosystems: The role of Nutrients, Kruger, F.J. Mitchel, D.T. and Jarvis J.U.M. (Eds.), Springer, Berlin.

14. Nakos G. (1980), Pollution of soil and vegetation in the Thriasian plain, Greece, Plant and Soil, 66, 271-277

15. Oszlányi J., (1997), Forest health and environmental pollution in Slovakia, Environmental pollution, 98(3), 389-392.

16. Papadopoulos A.M., Pantera A., Goudelis G., Raftogiannis I. Stamatopoulos E. and Vergos S., (2005), Sensitivity of tree rings of Aleppo pine (Pinus halepensis Mill.) to climatic conditions for the period 1960-2003 at the basin of Attica, In: Forest and Water, Proceedings of the $12^{\text {th }}$ Forest Scientific Society Congress held in Drama, Greece.

17. Papadopoulos A.M., Serre-Bachet F. and Tessier L., (2001), Tree ring to climate relationships of Aleppo pine (Pinus halepensis Mill.) in Greece, Ecologia Mediterranea, 27(1), 89-98

18. Penninckx V., Meerts P., Herbauts J. and Gruber W., (1999), Ring width and element concentrations in beech (Fagus sylvatica L.) from a periurban forest in central Belgium, Forest Ecology and Management, 113, 23-33.

19. Rathgeber C., Nicault A., Guiot J., Keller T., Guibal F. and Roche P., (2000) Simulated responses of Pinus halepensis forest productivity to climatic change and $\mathrm{CO}_{2}$ increase using a statistical model, Global and Planetary Change, 26, 405-421.

20. Saitanis C.J., (2003), Background ozone monitoring and phytodetection in the grater rural area of Corinth - Greece, Chemosphere, 51, 913-923.

21. Schweingruber F.H., (1988), Tree Rings. Basic and Applications of Dendrochronology" D. Reidel, Dordrecht.

22. Serre-Bachet F., (1985), La dendrochronologie dans le basin méditerranéen, Dendrochronologia, 3, 77-92.

23. Serre-Bachet F., (1991), Tree-rings in the Mediterranean area, In: Evaluation of climate proxy data in relation to European Holocene, Frenzel et al. (eds), Gustav Fischer Verlag. 